\title{
A Cristologia Neopentecostal no Brasil pós-moderno: continuidade e ruptura
}

\author{
Orientador: Paulo Cezar Costa
}

Doutorando: Carlos José de Oliveira

Área de Concentração: Teologia Sistemático-Pastoral

Linha de Pesquisa: Fé e Cultura

A Cristologia Neopentecostal no Brasil pós-moderno: continuidade e ruptura é o tema deste trabalho que visa abordar o complexo cenário religioso brasileiro e identificar o Cristo neopentecostal e perquirir os elementos de continuidade e ruptura com a cristologia bíblico-eclesial. Parte-se de uma visão panorâmica da pós-modernidade e suas características, para compreender o contexto sócio-cultural no qual está inserido este movimento que tem origem no pentecostalismo americano, mas chegou ao Brasil em meados do século XX e tornou-se um forte fenômeno midiático de grande impacto. Busca-se apresentar o processo de emancipação, a partir dos aspectos históricos, suas principais doutrinas, ritos e características, em especial a estrutura teológica denominada como Teologia da Prosperidade. Compreendendo a estrutura fundamental, o trabalho investiga o neopentecostalismo em seus diferentes ângulos, identificando os elementos centrais da sua cristologia para, então, apontar elementos de continuidade e ruptura em relação à cristologia bíblico-eclesial. Jesus é apresentado a partir de imagens e elementos próprios da teologia neopentecostal: é um Jesus rico e saudável, empreendedor, líder autoconfiante, um verdadeiro super-herói, milagreiro, que responde com facilidade às necessidades de saúde, econômicas, sentimentais; um Jesus taumaturgo, produtor de milagres, prodígios, curas; um Jesus que responde às necessidades mais imediatas da pessoa humana, com o qual se estabelece uma relação funcional, meramente sentimental e de interesse; um Jesus da solução e não tanto da salvação. Esta cristologia se coaduna com a pós-modernidade, pois esta se caracteriza por um forte retorno ao sagrado sem foco bem-definido, uma 
transcendência sem rosto, sem conteúdo. Por isso, a cristologia neopentecostal caminha da continuidade à ruptura com a cristologia da Tradição cristã, aquela denominada Bíblico-Eclesial.

Palavras-chave: Cristologia. Neopentecostalismo. Pós-modernidade. 